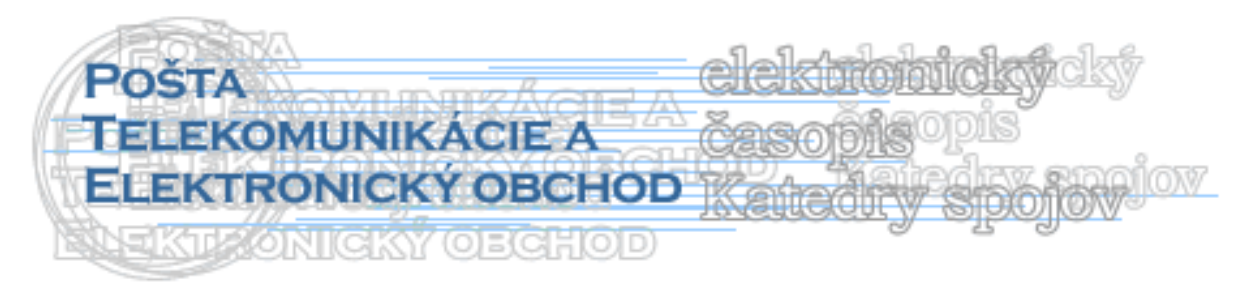

\title{
NEKONČIACA IMPLEMENTÁCIA METÓDY SIX SIGMA V SPOLOČNOSTI
}

\begin{abstract}
Anna Pad'ourová*
Úvod

Metóda Six Sigma je logickým pokračovaním viac ako sedemdesiatročného vývoja prístupu k zabezpečovaniu kvality. Táto metóda zabudovává štatistiku do života firmy, čo so sebou prináša potrebu nového pohl'adu, alebo skôr dvoch pohl'adov. Prvý je vnútorný pohl'ad na celý firemný proces, ktorý predstavuje potrebu neustále mysliet' na to, že dôležitý je až konečný výsledok firmy. Druhým dôležitým pohl'adom je pohl'ad z pozície zákazníka. Aj ked' ide o dva protichodné pohl'ady na správanie sa firmy celkovo, sú spolu medzi sebou vel'mi pevne previazané. Bez umenia pozriet' sa na problém očami zákazníka je len vel'mi t’ažké dosiahnut' akékol'vek riešenie.

Presadzovanie metódy Six Sigma prístupu v rámci firmy nestačí na splnenie vytýčených ciel’ov. Prelomom vimplementácii nástrojov Six Sigma je schválenie projektu, ktorý zabezpečuje určitý stupeň Six Sigma kvalifikácie každému pracovníkovi firmy bez ohl'adu na zastávanú pozíciu.
\end{abstract}

\section{Organizačné zmeny v štruktúre Six Sigma}

Filozofia Six Sigma je postavená na princípe vyškolenia širokého okruhu pracovníkov na nevyhnutný štandard umožňujúci pochopit' dianie v rámci projektu a podporit' jeho výsledok z pozície člena tímu, a to bud' ako Green Belt či White Belt. Projektovým manažérom sa stáva Black Belt, s komplexným Six Sigma vzdelaním, skúsenost'ami a praxou $\mathrm{z}$ tréningov a predchádzajúcich projektov. Black Belt je vyčlenený z bežných organizačných štruktúr a zároveň na $100 \%$ pridelený na doriešenie zvoleného problému. Tento postup musí byt' striktne dodržiavaný od počiatku implementácie Six Sigma vo firme.

Neskôr vzniká medzera medzi ostatnými štruktúrami závodu a Six Sigma organizáciou, čo vyvoláva kontraproduktívne správanie sa pracovníkov, hlavne vo výrobných prevádzkach, ktorých nezainteresovaná pozícia Black Beltov vedie k pocitu menšej spoluzodpovednosti za výsledok. A na strane opačnej aj Black Belti vyčlenení zo štruktúr časom strácajú kontakt s výrobou a začínajú inklinovat' k teoretickým prístupom s dôrazom na prezentačné praktiky.

Na zlepšenie situácie sa začala postupne menit' organizácia Six Sigma tak, že Black Belti po vyškolení a vyriešení prvého projektu ostávajú v pôvodných organizačných štruktúrach závodu a pokračujú vo svojej funkcii. Pri vzniku potreby riešit' projekt z ich pôsobnosti sú na čiastkový úväzok povytiahnutí zo svojej pozície

\footnotetext{
* Ing. Anna Pad’ourová, PhD., Žilinská univerzita v Žiline, Fakulta prevádzky a ekonomiky dopravy a spojov, Katedra spojov, Univerzitná 1, 01026 Žilina, tel.: +421041/5133129, fax: +421041/5655 615

e-mail: anna.padourova@fpedas.uniza.sk
} 
a s využitím už nadobudnutých Six Sigma znalostí a vedomostí sa venujú riadeniu tímu pracovníkov počas riešenia projektu. Tým, že prešli komplexným tréningom, je predpoklad, že ich aktivity budú štandardizované a harmonizované s inými projektovými lídrami využívajúce tie isté vedomosti pre riešenie iných projektov. Táto forma Black Beltov sa nazýva Funkčný Black Belt. Teda je to kombinácia Black Belta na plný úväzok a pracovníkom na svojej trvalej pozícii pred absolvovaním Black Belt tréningu.

\section{Členenie organizácie Six Sigma}

Six Sigma sa realizuje prostredníctvom vlastných zamestnancov podniku. Zamestnanci predstavujú najdôležitejšie riešitel'ské kapacity zlepšovania. Orientácia na zákazníkov, procesy a zamestnancov, robí zo Six Sigma spôsob budovania a rozvíjania novej podnikovej kultúry. Vnútropodnikovú organizáciu Six Sigma môžeme vidiet' na obr. 1.

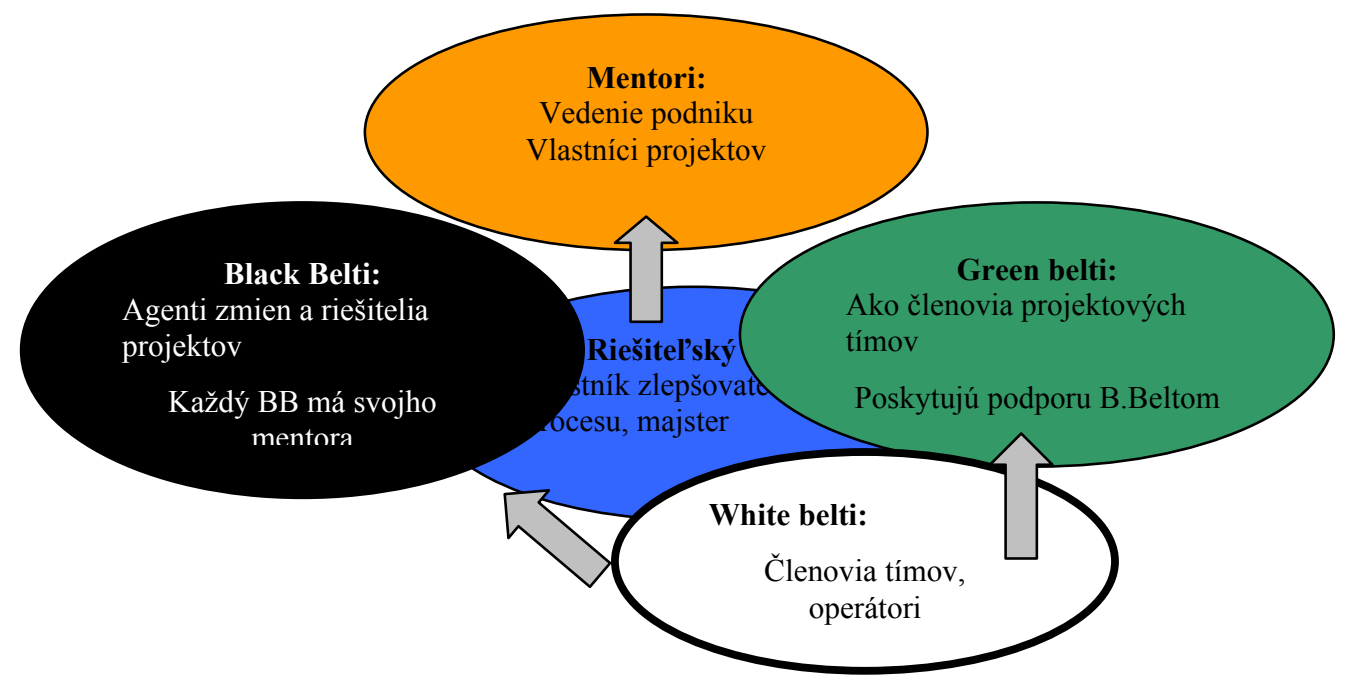

Obr. 1 Vnútropodniková organizácia programu Six Sigma

\section{Prehl’ad úloh a kvalifikácií Six Sigma}

Tab. 1. Rozdelenie kvalifikácií Six Sigma

\begin{tabular}{|c|c|c|c|}
\hline Typ & Profil & Činnosti & Počet \\
\hline Green Belt & $\begin{array}{l}\text { Uznávaný a rešpektovaný, } \\
\text { schopný previest' údaje na } \\
\text { informácie, znalec } \\
\text { nástrojov }\end{array}$ & $\begin{array}{l}\text { vedie tímy zlepšovania procesov, } \\
\text { radí a trénuje používanie nástrojov } \\
\text { a vykonávanie analýz, }\end{array}$ & $\begin{array}{l}1 \text { na } 20 \\
\text { zamestnan } \\
\text { cov firmy }\end{array}$ \\
\hline $\begin{array}{c}\text { Black } \\
\text { Belt }\end{array}$ & $\begin{array}{l}\text { Rešpektovaný kolegami } \\
\text { a manažmentom, znalec } \\
\text { pokročilých nástrojov, } \\
\text { schopný previest' údaje na } \\
\text { informácie }\end{array}$ & $\begin{array}{l}\text { vedie strategické projekty } \\
\text { s významným dopadom na } \\
\text { výkonnost' procesov, agent zmien, } \\
\text { vykonáva tréning a vedie } \\
\text { multifunkčné tímy riešitel'ov, } \\
\text { pracuje ako BB Six Sigma na plný } \\
\text { úväzok }\end{array}$ & $\begin{array}{l}1 \text { na } 50- \\
100 \\
\text { zamestnan } \\
\text { cov firmy }\end{array}$ \\
\hline $\begin{array}{c}\text { Master } \\
\text { Black Belt }\end{array}$ & $\begin{array}{l}\text { Technicky dokonalé } \\
\text { znalosti aplikovat' nástroje } \\
\text { Six Sigma, skúsený } \\
\text { komunikátor, uznávaný } \\
\text { vzor a líder Six Sigma na } \\
\text { všetkých úrovniach }\end{array}$ & $\begin{array}{l}\text { mentor techník a nástrojov BB } \\
\text { a GB, interný konzultant a tréner } \\
\text { Six Sigma, inovátorský prístup } \\
\text { Six Sigma, člen vedenia Six } \\
\text { Sigma }\end{array}$ & $\begin{array}{l}10 \% \text { počtu Black } \\
\text { Beltov. }\end{array}$ \\
\hline
\end{tabular}




\begin{tabular}{|l|l|l|l|}
\hline & podniku & & \\
\hline Mentor & Top manažér, & poskytuje zdroje a podporu & 1 na organizačnú \\
& rešpektovaný líder & vedenia projektom, presadzuje & jednotku. \\
& a mentor v riešení & víziu, tvorí plán a štruktúru & \\
& podnikových záležitostí, & programu, definuje ukazovatele, & \\
& kvalifikovaný a silný líder & vyčísluje výnosy, je členom & \\
& $\begin{array}{l}\text { Six Sigma kladúci správne } \\
\text { otázky, vedie BB v }\end{array}$ & vedenia Six Sigma, & \\
& zásadných otázkach & & \\
\hline
\end{tabular}

\section{Základné kritériá pre výber projektov}

a) Očakávané prínosy a výsledky dopadu na zákazníka a požiadavky

$\Rightarrow$ dopad na obchodnú stratégiu a konkurencieschopnost';

$\Rightarrow$ dopad na budovanie klúčovej kompetencie podniku;

$\Rightarrow$ následnost' či závislost';

$\Rightarrow$ finančný dopad;

$\Rightarrow$ naliehavost';

$\Rightarrow$ trend.

b) Realizovatel'nost'

$\Rightarrow$ potrebné zdroje;

$\Rightarrow$ aké odborné znalosti máme k dispozícii;

$\Rightarrow$ komplexnost';

$\Rightarrow$ pravdepodobnost' úspechu;

$\Rightarrow$ podpora.

c) Dopad na organizáciu

$\Rightarrow$ čo sa môžeme naučit';

$\Rightarrow$ medziprevádzkové výhody.

\section{Záver}

Prínosy implementácie metodológie Six Sigma je možné stručne zhrnút' do týchto základných charakteristík:

- „Six Sigma“ zabezpečuje trvalý úspech - jediný spôsob ako udržat' rast podniku a ovplyvňovat' situáciu na trhu je nepretržité inovovanie a reorganizovanie.

- „Six Sigma“ stanovuje výkonnostný ciel' - v podniku je t’ažké prinútit' všetkých pracovat' rovnakým spôsobom a zamerat' úsilie zamestnancov na spoločný ciel'. Každá funkcia, podnikový útvar a jednotliví zamestnanci majú rozdielne plány, ciele a úlohy. Každý podnik, ktorý porozumie požiadavkám svojich zákazníkov môže svoju výkonnost' porovnat' s ciel'om stanoveným podl'a koncepcie Six Sigma.

- „Six Sigma“ vyzdvihuje význam zákazníka podniku - pri tvrdej konkurencii v liberalizujúcom sa prostredí nie je možné zabezpečit' obchodný úspech dodávaním iba dobrého a bezchybného tovaru. Podstatou Six Sigmy je venovat' zvláštnu pozornost' potrebám zákazníkov a poznat', čo je pre zákazníka dôležité.

- „Six Sigma“ akceleruje tempo zlepšovania - podnik, ktorý sa zlepšuje najrýchlejšie pravdepodobne vyhrá konkurenčný boj na ciel'ovom trhu, preto je do Six Sigmy zapracovaných mnoho techník a nástrojov z rôznych oblastí riadenia a inovácií.

- „Six Sigma“ propaguje vzdelávanie - je dokázané, že Six Sigma môže zvýšit' a urýchlit’ vznik a aplikovanie nových myšlienok v podniku. Nápady je možné lepšie aplikovat' a ich účinok porovnávat' prostredníctvom jasne definovanej výkonnosti meranej v jednotkách Six Sigma. 
- „Six Sigma“ pomáha uskutočňovat' v podniku strategické zmeny v podobe nových, inovatívnych produktov, nových projektov, vstupu na nové ciel'ové trhy a podobne. Zrozumitel'nost' postupov pri implementácii Six Sigmy v podniku poskytuje príležitost' k uskutočňovaniu jednak menších úprav, ale aj významných podnikových zmien, ktoré sú predpokladom rastu konkurencieschopnosti a stability podniku na novovytvárajúcom sa globálnom trhu.

Grantová podpora:

Spracovanie tohto príspevku nadväzuje na riešenie projektu MVTS NEM/SR/ŽU3/07 „Aplikácia cyklu PDCA v službách ako faktor zvyšovania efektívnosti riadenia“ a projektu VEGA 1/0468/08 „Inovačné stratégie v sektore služieb“, ktoré sú riešené na Katedre spojov, FPEDAS, ŽU v Žiline.

\section{Použitá literatúra}

[1] PANDE, P., NEUMANN, R. P., CAVANAGH, R. R.: Zavádíme metodu Six Sigma, Brno 2002

[2] TOŠENOVSKÝ, J.: Strategie Six Sigma s využitím Balanced Scorecard. Elektronická učebnica na CD. Ostrava. Dom techniky, 2003

[3] JANEČEK, Z.: Six Sigma trochu jinak, Svět jakosti 1, 2002

[4] HERGENRÖDER, E., BACHMANN, F., VACULÍK, J.: Marketing and quality attributes in different structure and services providing by consultant office. ŽU v Žiline. Ekonomicko-manžérske spektrum. ISSN 1337 - 0839. v tlači

[5] ROSTÁŠOVÁ, M., KREMEŇOVÁ, I.: Marketing v službách - Algoritmy marketingových činností. / 2005. Žilina, Vydavatel'stvo EDIS, 2005. ISBN 80-8070355-8.

[6] http://www.msys.sk/six-sigma.htm 